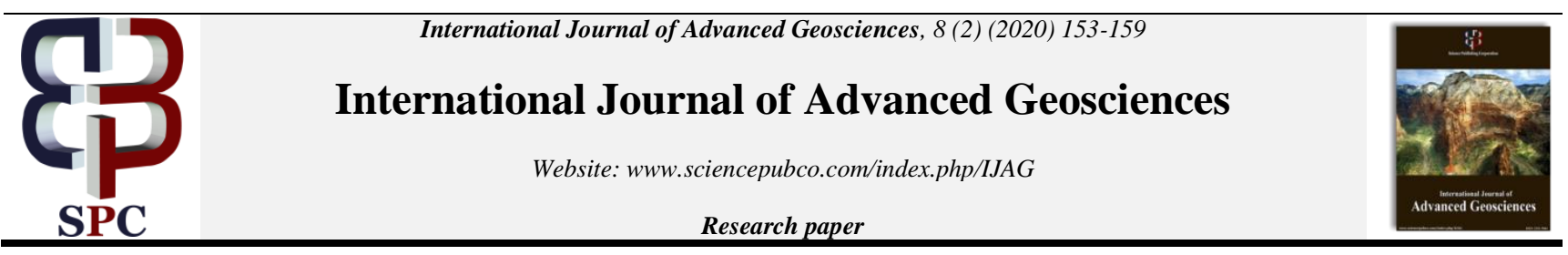

\title{
Yield, quality and cost of jute (Corchorus species) seed production as influenced by herbicide application time
}

\author{
Md. Meftahul Karim ${ }^{1}{ }^{*}$, Md. Lutfar Rahman ${ }^{1}$, Jannatul Ferdush ${ }^{1}$, Md. Zablul Tareq ${ }^{1}$, Md. \\ Mukul Mia ${ }^{1}$, Md. Tipu Sultan and ${ }^{1}$, Raihan Mujib Himel ${ }^{2}$ \\ ${ }^{1}$ Bangladesh Jute Research Institute, Manik Mia Avenue, Dhaka 1207, Bangladesh \\ ${ }^{2}$ Bangladesh Tea Research Institute, Srimangal, Bangladesh \\ *Corresponding author E-mail: karimmeftahul@gmail.com
}

\begin{abstract}
Jute is the most important fibre crop for Bangladesh and second important for world. Bangladesh requires about 6000 tons of jute seed. Among this quantity Bangladesh produce whole amount of Corchorus capsularis L. (white jute) seed but only very little amount of Corchorus olitorius L. (tossa jute) seed. Production of tossa jute seed is not too profitable because of high production cost for that reason farmers of Bangladesh are not interested to produce seed of tossa jute. And production cost of jute seed is mainly associated with labor cost that is mainly for weeding. This study was conducted to assess the best herbicide application time to enhance seed productivity, quality and reduction the cost of production. In this experiment two Corchorus species were grown using three different herbicide application times and no herbicide application used as control. The results indicated that for tossa jute (BJRI tossa pat-8) maximum plant population, plant height, branch/plant, capsule/plant, seed/capsule, seed yield, germination capacity, field emergence capacity, seed vigour and CVG were found in Control plot. Maximum 1000 seed weight and MGT were recorded in herbicide applied at 13th days after cutting transplanting. Maximum capsule length found at 10th days of herbicide application. For white jute (CVL-1) highest plant population, plant height, branch/plant, seed/capsule, capsule length, germination capacity, field emergence capacity, seed vigour and CVG were recorded in control plot. Highest capsule/plant, 1000 seed weight and seed yield were found in herbicide applied at 13th days after cutting transplanting. Maximum MGT found in herbicide applied at 16th days after cutting transplanting. Result revealed that herbicide use reduce the production cost of jute seed compare to manual seed production technology.
\end{abstract}

Keywords: Jute Seed; Herbicide Application Time; Yield and Quality.

\section{Introduction}

Jute is the second most important bast fibre crop after cotton in terms of global consumption. It is an important cash crop in Bangladesh and India, which together accounts for about $84 \%$ of world production of jute fibre (Hossain et al., 2002). Jute alone contributes about $1.58 \%$ to GDP without involving any foreign investment. In 2015-2016, 1360608.12 tons of jute fibre was produced from 677678 hectares of land that covers about $4.46 \%$ of total land area (BBS, 2018). Jute is a completely biodegradable, recyclable and eco-friendly lingo-cellulose fiber (Mir et al., 2008). Global awareness on 'save the environment' increases the demand of jute. Jute and jute products not only retard ecological degradation but also conserve green environment and atmosphere as a whole (Ghosh et al., 2013, Mamun et al., 2017). The jute fibers are derived from the bark of the plant. The genus Corchorus belongs to the family Malvaceae, which is composed of approximately 100 species (Saunders, 2001). Of these, two species (Corchorus olitorius L. and Corchorus capsularis L.) are widely cultivated for natural fiber in areas distributed throughout the tropical and sub-tropical regions of the world, particularly in Asia, Africa and Latin America (Hossain et al., 2002). In Bangladesh Corchorus capsularis L. is known as white jute and Corchorus olitorius L. known as tossa jute. About $91 \%$ of total jute cultivable area covered by tossa jute and rest of the covered by white jute (Saha, 2011). Seed is a basic input for any crop production program, which leads inevitably for agricultural change of a country but Bangladesh has been facing an acute shortage of quality jute seed every year (Hossen et al., 2008). Bangladesh requires about 5500-6000 tons jute seeds in every year, of which only $10-15 \%$ is produced and distributed by the BADC (Ali et al., 2003). It is to be noted that the total need of deshi (Corchorus capsularis L.) seeds is being met by the country itself through domestic source. For tossa jute seed Bangladesh mainly depend on neighboring country. On the other hand, jute seed production areas are decreasing at an alarming rate due to unavailability of land. As a result, every year a huge amount of tossa jute seeds are introducing through official and unofficial trades from neighboring country. Unofficial imports of jute seed have no guarantee of its quality and are one of the major causes of low yield (Islam, 2009). Due to supply of insufficient quantity seed from the public sector and due to high demand of jute seed, sometimes unauthorized traders are taking the opportunity of introducing poor quality seeds in the market. So it is necessary to check unauthorized traders by increasing jute seed production in the country. 
Weed flora in jute field varies depending upon the agro-ecological conditions, management practices and cropping systems followed in particular location. Out of 129 species of both monocotyledonous and dicotyledonous jute weeds generally found in Bangladesh belonging to 99 genera or 39 families (Islam, 2014). The hot and humid environment and wet soil in early growth stage of jute seed production are highly favorable for jute weed germination and growth. About $54 \%$ of the total cost of production goes to weeding and thinning if done manually (Alam, 2003) and thereby drastically reduce profitability. Now-a-days, availability of manual labour and ever rising cost has made the jute cultivation non-profitable. To resolve this problem, herbicide is a wise option to manage weeds as it is a low cost, less labour and time demanding; and target specific method of weed control (Gianessi, 2013., Parvez et al. 2013., Simmons, 2006). Herbicides are typically used for controlling weeds by applying in soil or foliage. Weeds competed with jute crops for water, light and mineral nutrients, which directly reduce the quality and quantity seed. Jute weeds indirectly reduce seed yield by serving as alternate host for diseases and pests. The traditional methods for control were observed hand pulling, pressing by foot, weeding by khurpy or weeder or by racker. These traditional methods of weed control are highly costly that increase the cost of jute seed production. So, benefit cost ratio for jute seed production is not favorable to farmer. For that cause they are not interested to produce jute seed. Use of herbicides for weed control have been increased tremendously in crops like rice, wheat, soybean etc. but farmers seldom use herbicide in jute because very few selective herbicides are available in the market for jute. Lack of awareness and technical know-how about the use of herbicides among the farmers often lead to phytotoxicity in crop. However, weed control through selective herbicides as pre- or post-emergence herbicides or directed spray of post emergence herbicides have been found .effective and economical for weed management in jute (Ghorai, et al., 2013). After certain period of weed growth it is not responsive to herbicide. Application time of herbicide is very crucial for seed yield and quality (Bennett and Shaw, 2000, Wilson and Smith, 2002, Zhang et al., 2016). However, among the available postemergence herbicides, only quizalofop ethyl was found effective in controlling grassy weeds of jute (Ghorai et al., 2004). However, post emergence application of fenoxapropp- ethyl at $75 \mathrm{~g} / \mathrm{ha}$ gave higher fiber and stick yield of jute (Sarkar. 2006). But, till date, literature is meager to understand the effect of herbicides application time on seed yield and quality of jute. To ensure higher seed yield in any crop, effective weed management at appropriate time with suitable methods is imperative. In view of these facts and paucity of adequate evidences on effects of herbicides in relation to jute seed production and quality the present study was undertaken to evaluate the effectiveness of herbicides for grassy weed suppression in Bangladesh.

\section{Materials and methods}

\subsection{Experimental site and soil}

The experiment was conducted at the research field in Jute Agriculture Experimental Station, Manikganj, during the month of August to December, 2019 in order to study the effect of herbicide application time on morpho-physiology, yield attributes and seed quality of two jute varieties e.g., BJRI tossa pat-8 (Corchorus olitorius L.) and CVL-1 (Corchorus capsularis L.). The experimental field was medium high land belonging to Old Brahmaputra-Jamuna flood plain (AEZ-8) having silt loam soil with pH 6.5. The soil contained $1.6 \%$ organic matter, $0.08 \%$ total nitrogen, 7.65 ppm available $\mathrm{P}, 0.23$ meq. $\mathrm{K} 100 \mathrm{~g}-1$, and $12.87 \mathrm{ppm}$ available $\mathrm{S}$.

\subsection{Experimental treatments and design}

This study consists of two jute varieties e.g., BJRI tossa pat- 8 and CVL-1 and three different herbicide application time $\left(\mathrm{T}_{0}\right.$ : Control, $\mathrm{T}_{1}$ : 10 days after cutting transplanting, $\mathrm{T}_{2}: 13$ days after cutting transplanting, $\mathrm{T}_{3}: 16$ days after cutting transplanting). For cutting 100 days old mother plant were used because in previous study showed 100 days old mother plant gave better yield (Alam et al., 2019). Experiment was conducted in Randomized Complete Block Design (RCBD) with three replications. In this study two post emergence herbicide sprayed separately in experimental field. Ethoxysulfuron and quizalofop Ethyl are active ingredients of the herbicide. Ghorai et al., 2004 reported that the quizalofop ethyl was effective in controlling grassy weeds of Jute. Dose of herbicide were determined according to manual of herbicide.

\subsection{Land preparation and crop management}

The experimental field was prepared with three ploughing and cross ploughing followed by laddering. The unit plot size was $2 \mathrm{~m} X 2 \mathrm{~m}$. Plot to plot distance was 1 meter.

The crop was fertilized with nitrogen, phosphorus, potash, boron and sulfur as per recommendation dose for jute seed production. Two weeding were done in $\mathrm{T}_{0}$ treatment first one in 20 days after cutting transplanting and second one in 45 days after cutting transplanting. For all other treatments no weeding was done. All other intercultural operations were done as per requirement.

\subsection{Harvesting and plant sampling}

When the matured seed (about $80 \%$ seed matures) of jute turned into blackish in color the plant sample were collected from each plot in treatment wise with proper tagged. Ten randomly selected plants were taken from each plot for getting accurate data. After threshing of capsule, seeds were cleaned and sun dried.

\subsection{Morpho-physiological characters, yield \& yield attributes}

Morpho-physiological characters namely plant height $(\mathrm{m})$ was measured with the help of scale meter. On the other hand yield and yield attributes viz. capsule length $(\mathrm{mm})$, capsule/plant, seeds/capsule, 1000 seed weight and seed yield ( $\mathrm{t} / \mathrm{ha})$ were determined by the standard method.

\subsection{Seed quality}

After threshing, sun dried seed were taken for quality testing with $9 \%$ moisture. For germination seeds were surface-sterilized first by a fungicide treatment (1 g L-1 Benlate) for 30 min, immersed in $6 \%$ calcium hypochlorite solution for 5 min, and then rinsed in $70 \%$ ethanol for $5 \mathrm{~min}$ and thoroughly washed with sterilized distilled water. Seeds were plated onto glass petri dishes ( $9 \mathrm{~cm}$ in diameter) contain- 
ing sterile perlite and placed in a growth chamber where the temperature and humidity were $25{ }^{\circ} \mathrm{C}$ and $80 \%$, respectively, with a photoperiod of $16 \mathrm{~h}$ day-1. Lighting was provided by OSRAM L36W/77 type lamps (FLUORA, white fluorescent tubes) providing an intensity of $1500 \mu \mathrm{mol} \mathrm{h-1}$ photon-1. Each petri dish contained 100 seeds. The parameters of the germination capacity (GC), germination kinetics, i.e. the mean germination time (MGT), the coefficient of velocity of germination (CVG), seed vigour, field emergence was determined by following formulas.

1) Germination capacity (GC)

$\mathrm{GC} \%=\mathrm{n} / \mathrm{N}^{*} 100$

Here, $\mathrm{n}$ is the total number of germinated seeds and $\mathrm{N}$ is the total number of tested seeds.

2) The coefficient of velocity of germination $(\mathrm{CVG})$

$\mathrm{CVG}=100 \times \Sigma \mathrm{Ni} / \Sigma \mathrm{NiTi}$

$\mathrm{Ni}=$ Number of germinated seeds per day and $\mathrm{Ti}=$ Number of days from the start of the experiment

3) The mean of germination time (MGT)

$\mathrm{MGT}=\Sigma \mathrm{NiTi} / \Sigma \mathrm{Ni}=100 / \mathrm{CVG}$

$\mathrm{Ni}=$ Number of seeds germinated per day and $\mathrm{Ti}=$ Number of days from the starting the experiment

4) Field Emergence (\%)

$\mathrm{FE}(\%)=\mathrm{n} / \mathrm{N}^{*} 100$

Here, $\mathrm{n}$ is the total number of germinated seeds in field condition and $\mathrm{N}$ is the total number of tested seeds

5) Vigour test

The test was conduct in laboratory with the same procedure as laboratory standard germination test. Vigour (Vigour value) was calculated following $17 \mathrm{~V}=\mathrm{a} / 1+\mathrm{b} / 2+\mathrm{c} / 3+\ldots \ldots$ where $\mathrm{V}=$ Vigour value and $\mathrm{a}, \mathrm{b}$ and $\mathrm{c}$ are the number of seed germinated after 1,2 and 3 days. The final count was made at the end of 6th days.

\subsection{Statistical analysis}

The recoded data on different parameters were statistically analyzed and partitioning the variance with the help of "MSTAT-C" software.

\subsection{Economic analysis}

For economic analysis, Jute production cost (cost required for land rent, purchasing of seed, mother plant collection and cutting transplanting cost, herbicide cost, fertilizers application, weeding cost, crop protection measures, irrigation, and harvesting) were added for the evaluation of jute seed production cost with different herbicide application time. Existing average market price of jute seed ( 1 USD = 84 BDT) was used to asses gross income. Net income was attained by excluding all expenses from gross income; and by dividing gross income with production cost, benefit-cost ratio (BCR) was investigated (Shah et al., 2013).

\section{Results and discussion}

\subsection{Effect of herbicide on crop}

Herbicide did not show any naked eye visible phytotoxic symptom in jute plant at any stage of crop growth in terms of epinasty, hyponasty, chlorosis, necrosis, scorching, wilting injury to leaf surface and leaf tip.

\subsection{Growth characteristics of late jute plant}

Genotypic characteristics of late jute plant are presented in table 1. The average maximum plant population $\left(5.82 \mathrm{~m}^{-2}\right)$ was recorded in $\mathrm{V}_{1}$ genotypes. Highest plant height $(3.11 \mathrm{~m})$ was found in $\mathrm{V}_{1}$ genotype. Maximum number of branch per plant $(26.26)$ was observed in $\mathrm{V}_{2}$ genotype that was statistically different from $\mathrm{V}_{1}$ genotype. Variation in plant population, plant height and branch per plant are genotypic. Influence of herbicide application time on growth characteristics of late jute plant are reported in table 2. Herbicide application time statistically significant influenced plant population of late jute. Maximum number of plant population $/ \mathrm{m}^{2}(5.97)$ was observed in $\mathrm{T}_{0}$ treatment and lowest was in $T_{1}$ similar result also found in previous study (datta et al., 2017). Plant height of late jute was not statistically influenced, topmost plant height was recorded in $\mathrm{T}_{0}$ treatment. Herbicide showed negative impact on branch number of late jute plant. Interaction effect of herbicide application time and genotypes on growth characteristics of late jute plant are presented in table 3 . In case of plant population, maximum plant number (6.43) was found in $\mathrm{V}_{1} * \mathrm{~T}_{0}$ treatment combination that was statistically different from other treatment combinations. For Chorchorus capsularis L. highest pant population was found in $\mathrm{V}_{2} * \mathrm{~T}_{0}$ combination. Topmost plant height (3.17) was recoded in $\mathrm{V}_{1} * \mathrm{~T}_{0}$ treatment combination and lowest plant height (2.93) was observed in $\mathrm{V}_{2} * \mathrm{~T}_{3}$ treatment combination. Number of branch per plant was significantly different for two genotypes. Maximum number (28.20) of branch per plant was recorded in $\mathrm{V}_{2} * \mathrm{~T}_{0}$ treatment combination that was statistically similar to $\mathrm{V}_{2} * \mathrm{~T}_{2}$ combination. Lowest number of branch/plant (12.57) was found in $\mathrm{V}_{1} * \mathrm{~T}_{2}$ treatment combination.

Table 1: Effect of Genotypes on Growth Characteristics of Late Jute Plant

\begin{tabular}{llll}
\hline Genotypes & Plant population $\left(\mathrm{m}^{-2}\right)$ & Plant height $(\mathrm{m})$ & Branch/Plant \\
\hline $\mathrm{V}_{1}$ & $5.82 \mathrm{a}$ & $3.11 \mathrm{a}$ & $13.33 \mathrm{~b}$ \\
$\mathrm{~V}_{2}$ & $5.08 \mathrm{~b}$ & $2.98 \mathrm{~b}$ & $26.26 \mathrm{a}$ \\
$\mathrm{LSD}$ & 0.51 & 0.10 & 1.46
\end{tabular}


CV $(\%)$

10.77

3.82

8.44

$\mathrm{V}_{1}$ : BJRI tossa pat-8; $\mathrm{V}_{2}$ : CVL-1.

Table 2: Effect of Herbicide Application Time on Growth Characteristics of Late Jute Plant

\begin{tabular}{|c|c|c|c|}
\hline Herbicide application time & Plant population $\left(\mathrm{m}^{-2}\right)$ & Plant height $(\mathrm{m})$ & Branch/Plant \\
\hline $\mathrm{T}_{0}$ & $5.97 \mathrm{a}$ & $3.10 \mathrm{a}$ & $21.14 \mathrm{a}$ \\
\hline $\mathrm{T}_{1}$ & $5.17 \mathrm{~b}$ & $3.06 \mathrm{~b}$ & $19.55 \mathrm{ab}$ \\
\hline $\mathrm{T}_{2}$ & $5.38 \mathrm{ab}$ & $3.05 \mathrm{a}$ & $20.22 \mathrm{ab}$ \\
\hline LSD & 0.72 & 0.14 & 2.06 \\
\hline $\mathrm{CV}(\%)$ & 10.77 & 3.82 & 8.44 \\
\hline
\end{tabular}

$\mathrm{T}_{0}$ : Control, $\mathrm{T}_{1}$ : herbicide application at $10^{\text {th }}$ days after cutting transplanting, $\mathrm{T}_{2}$ : herbicide application at $13^{\text {th }}$ days after cutting transplanting, $\mathrm{T}_{3}$ : herbicide application at $16^{\text {th }}$ days after cutting transplanting.

Table 3: Interaction Effect of Genotypes and Herbicide Application Time on Growth Characteristics of Late Jute Plant

\begin{tabular}{|c|c|c|c|}
\hline Treatments combinations & Plant population $\left(\mathrm{m}^{-2}\right)$ & Plant height $(\mathrm{m})$ & Branch/Plant \\
\hline $\mathrm{V}_{1} \times \mathrm{T}_{0}$ & $6.43 \mathrm{a}$ & $3.17 \mathrm{a}$ & $14.08 \mathrm{c}$ \\
\hline $\mathrm{V}_{1} \times \mathrm{T}_{1}$ & $5.17 \mathrm{bc}$ & $3.13 \mathrm{ab}$ & $13.77 \mathrm{cb}$ \\
\hline $\mathrm{V}_{1} \times \mathrm{T}_{2}$ & $5.75 \mathrm{ab}$ & $3.12 \mathrm{ab}$ & $12.57 \mathrm{c}$ \\
\hline $\mathrm{V}_{1} \times \mathrm{T}_{3}$ & $5.92 \mathrm{ab}$ & $3.02 \mathrm{ab}$ & $12.90 \mathrm{c}$ \\
\hline $\mathrm{V}_{2}{ }^{\mathrm{x}} \mathrm{T}_{0}$ & $5.50 \mathrm{abc}$ & $3.03 \mathrm{ab}$ & $28.20 \mathrm{a}$ \\
\hline $\mathrm{V}_{2}{ }^{\mathrm{x}} \mathrm{T}_{1}$ & $5.17 \mathrm{bc}$ & $2.98 \mathrm{ab}$ & $25.33 \mathrm{ab}$ \\
\hline $\mathrm{V}_{2}{ }^{\mathrm{x}} \mathrm{T}_{2}$ & $5.00 \mathrm{bc}$ & $2.99 \mathrm{ab}$ & $27.87 \mathrm{a}$ \\
\hline $\mathrm{V}_{2}{ }^{\mathrm{x}} \mathrm{T}_{3}$ & $4.67 \mathrm{c}$ & $2.93 \mathrm{~b}$ & $23.63 \mathrm{~b}$ \\
\hline $\mathrm{CV}(\%)$ & 10.77 & 3.82 & 8.44 \\
\hline
\end{tabular}

\subsection{Seed yield and yield attributes of late jute}

Genotypic influence on jute seed yield and yield attributes are reported in table 4. Jute genotypes had statistically significant effect on capsule number per plant. Maximum capsule number (361.63) was recorded in $\mathrm{V}_{2}$ (CVL-1.) genotype and lowest in $\mathrm{V}_{1}$ (BJRI tossa pat8) genotype. Seed per capsule was highest (190.27) in $V_{1}$ genotype that was statistically different from $V_{2}$ genotype this result was supported by das et al., 2014. Highest 1000 seed weight (3.90g) was found in $\mathrm{V}_{2}$ genotype that was statistically different from $\mathrm{V}_{1}$ genotype. Maximum capsule length $(67.78 \mathrm{~mm})$ was found in $\mathrm{V}_{1}$ genotype. Seed yield $(1.40 \mathrm{t} / \mathrm{ha})$ of $\mathrm{V}_{2}$ genotype was maximum and statistically different from $V_{1}$ genotype. Variation in capsule per plant, seed per capsule, 1000 seed weight and seed yield were genotypic.

Impact of herbicide application time on late jute seed yield and yield attributes are presented in table 5. Control treatment with no herbicide application produced maximum number (265.77) of capsule per plant that was statistically identical to herbicide application at $10^{\text {th }}$ days $\left(T_{1}\right)$ of cutting transplanting. Minimum number of capsule per plant was recorded in herbicide application at $16^{\text {th }}$ days of cutting transplanting because herbicide application in later stage hamper plant growth and development. Number of seed per capsule varied due to herbicide application time, maximum number was recorded (119.61) in control plot and lowest number (110.66) was in $\mathrm{T}_{2}$ treatment. Topmost 1000 seed weight was found in herbicide application at $16^{\text {th }}$ days of cutting transplanting that was statistically akin to other treatments. Highest capsule length $(40.46 \mathrm{~mm})$ was found in $\mathrm{T}_{1}$ treatment that was statistically identical to other herbicide application time. Maximum late jute seed yield (1.21 t/ha) was reported in control treatment (no herbicide application) that was statistically akin to herbicide application at $13^{\text {th }}$ days of cutting transplanting $\left(\mathrm{T}_{2}\right)$. Least amount of late jute seed yield was recorded in $\mathrm{T}_{3}$ treatment. Herbicide application and application time significantly influenced the seed yield of late jute. This result is supported in foregoing study (sinha et al., 2009).

There was a significant interaction effect of herbicide application time and genotypes on capsule per plant, seed per capsule, 1000 seed weight, capsule length and seed yield of late jute seed (table 6). Number of capsule per plant was maximum (391.97) in $\mathrm{V}_{2} * \mathrm{~T}_{2}$ treatment combination that was statistically akin to $\mathrm{V}_{2} * \mathrm{~T}_{0}$ treatment combination. Least amount (117.00) of capsule per plant was recorded in $\mathrm{V}_{1} * \mathrm{~T}_{3}$ treatment combination that was statistically identical to $\mathrm{V}_{1} * \mathrm{~T}_{0}, \mathrm{~V}_{1} * \mathrm{~T}_{1}, \mathrm{~V}_{1} * \mathrm{~T}_{2}$ treatment combinations. Highest number (200.00) of seed per capsule was found in $\mathrm{V}_{1} * \mathrm{~T}_{0}$ treatment combination that was statistically different from other treatment combinations and minimum number (35.40) seed per capsule was recorded in $\mathrm{V}_{2} * \mathrm{~T}_{1}$ treatment combination. Maximum 1000 seed weight (4.01 g) was found in $\mathrm{V}_{1} * \mathrm{~T}_{2}$ treatment combination that was statistically similar to $\mathrm{V}_{2} * \mathrm{~T}_{0}, \mathrm{~V}_{2} * \mathrm{~T}_{1}$ and $\mathrm{V}_{2} * \mathrm{~T}_{3}$ treatment combinations. Least amount of 1000 seed weight $(2.36 \mathrm{~g})$ was recorded in $\mathrm{V}_{1} * \mathrm{~T}_{1}$ treatment combination. Highest capsule length $(69.86 \mathrm{~mm})$ was recorded $\mathrm{V}_{1} * \mathrm{~T}_{1}$ treatment combination that was closely followed by $\mathrm{V}_{1} * \mathrm{~T}_{3}(67.78 \mathrm{~mm}), \mathrm{V}_{1} * \mathrm{~T}_{0}(67.37 \mathrm{~mm})$ and $\mathrm{V}_{1} * \mathrm{~T}_{2}(6613 \mathrm{~mm})$. The minimum capsule length $(11.07 \mathrm{~mm})$ was observed in $\mathrm{V}_{2} * \mathrm{~T}_{1}$ treatment combination. Maximum amount of seed yield $(1.52 \mathrm{t} / \mathrm{ha})$ was recorded in $\mathrm{V}_{2} * \mathrm{~T}_{2}$ treatment combination that was statistically identical to $\mathrm{V}_{2} * \mathrm{~T}_{0}$ treatment combination. Minimum amount of seed yield (0.80 t/ha) was recorded in $\mathrm{V}_{1} * \mathrm{~T}_{3}$ treatment combination that was statistically akin to $\mathrm{V}_{1} * \mathrm{~T}_{0}, \mathrm{~V}_{1} * \mathrm{~T}_{1}$ and $\mathrm{V}_{1} * \mathrm{~T}_{2}$ treatment combinations.

Table 4: Effect of Genotypes on Seed Yield and Yield Attributes of Late Jute

\begin{tabular}{|c|c|c|c|c|c|}
\hline Genotypes & Capsule/plant & Seed/capsule & 1000 seed weight $(\mathrm{g})$ & Capsule length (mm) & Seed yield (t/ha) \\
\hline $\mathrm{V}_{1}$ & $1129.99 \mathrm{~b}$ & $190.27 \mathrm{a}$ & $2.47 \mathrm{~b}$ & $67.78 \mathrm{a}$ & $0.87 \mathrm{~b}$ \\
\hline $\mathrm{V}_{2}$ & $361.63 \mathrm{a}$ & $36.76 \mathrm{~b}$ & $3.90 \mathrm{a}$ & $11.31 \mathrm{~b}$ & $1.40 \mathrm{a}$ \\
\hline LSD & 8.42 & 6.01 & 0.15 & 0.19 & 0.09 \\
\hline $\mathrm{CV}(\%)$ & 3.21 & 6.05 & 5.40 & 5.51 & 9.24 \\
\hline
\end{tabular}

$\mathrm{V}_{1}$ : BJRI tossa pat-8; $\mathrm{V}_{2}$ : CVL-1

Table 5: Effect of Herbicide Application Time on Seed Yield and Yield Attributes of Late Jute

\begin{tabular}{|c|c|c|c|c|c|}
\hline Herbicide application time & Capsule/plant & Seed/capsule & 1000 seed weight $(\mathrm{g})$ & Capsule length (mm) & Seed yield (t/ha) \\
\hline $\mathrm{T}_{0}$ & $265.77 \mathrm{a}$ & $119.61 \mathrm{a}$ & $3.17 \mathrm{a}$ & $39.46 \mathrm{a}$ & $1.21 \mathrm{a}$ \\
\hline $\mathrm{T}_{1}$ & $242.48 \mathrm{ab}$ & $111.43 \mathrm{ab}$ & $3.07 \mathrm{a}$ & $40.46 \mathrm{a}$ & $1.12 \mathrm{ab}$ \\
\hline $\mathrm{T}_{2}$ & $258.72 \mathrm{a}$ & $110.66 \mathrm{ab}$ & $3.24 \mathrm{a}$ & $38.74 \mathrm{a}$ & $1.17 \mathrm{ab}$ \\
\hline LSD & 4.20 & 8.50 & 0.21 & 2.69 & 0.12 \\
\hline $\mathrm{CV}(\%)$ & 3.21 & 6.05 & 5.40 & 5.51 & 9.24 \\
\hline
\end{tabular}


$\mathrm{T}_{0}$ : Control, $\mathrm{T}_{1}$ : herbicide application at $10^{\text {th }}$ days after cutting transplanting, $\mathrm{T}_{2}$ : herbicide application at $13^{\text {th }}$ days after cutting transplanting, $\mathrm{T}_{3}$ : herbicide application at $16^{\text {th }}$ days after cutting transplanting.

Table 6: Interaction Effect of Genotypes and Treatments on Growth Characteristics of Late Jute Plant

\begin{tabular}{lllll}
\hline Treatments combinations & Capsule/plant & Seed/capsule & $1000 \mathrm{seed}$ weight $(\mathrm{g})$ & Capsule length $(\mathrm{mm})$ \\
\hline $\mathrm{V}_{1} \times \mathrm{T}_{0}$ & $141.67 \mathrm{c}$ & $200.60 \mathrm{a}$ & $2.39 \mathrm{~b}$ & $67.37 \mathrm{a}$ \\
$\mathrm{V}_{1}{ }^{\times} \mathrm{T}_{1}$ & $135.83 \mathrm{c}$ & $187.47 \mathrm{~b}$ & $2.36 \mathrm{~b}$ & $69.86 \mathrm{a}$ \\
$\mathrm{V}_{1} \times \mathrm{T}_{2}$ & $125.47 \mathrm{c}$ & $184.60 \mathrm{~b}$ & $2.47 \mathrm{~b}$ & $66.13 \mathrm{a}$ \\
$\mathrm{V}_{1} \times \mathrm{T}_{3}$ & $117.00 \mathrm{c}$ & $188.43 \mathrm{~b}$ & $2.66 \mathrm{~b} \mathrm{c}$ & $0.90 \mathrm{c}$ \\
$\mathrm{V}_{2} \times \mathrm{T}_{0}$ & $389.87 \mathrm{a}$ & $38.61 \mathrm{c}$ & $3.94 \mathrm{a}$ & $0.83 \mathrm{c}$ \\
$\mathrm{V}_{2}{ }^{\times} \mathrm{T}_{1}$ & $349.13 \mathrm{ab}$ & $35.40 \mathrm{c}$ & $3.78 \mathrm{a}$ & $0.80 \mathrm{c}$ \\
$\mathrm{V}_{2} \times \mathrm{T}_{2}$ & $391.97 \mathrm{a}$ & $36.73 \mathrm{c}$ & $4.01 \mathrm{a}$ & $11.55 \mathrm{~b}$ \\
$\mathrm{~V}_{2} \times \mathrm{T}_{3}$ & $315.57 \mathrm{~b}$ & $36.31 \mathrm{c}$ & $3.88 \mathrm{a}$ & $11.07 \mathrm{~b}$ \\
$\mathrm{LSD}$ & 6.84 & 12.03 & 0.30 & $11.34 \mathrm{~b}$ \\
$\mathrm{CV}(\%)$ & 3.21 & 6.05 & 5.40 & $1.28 \mathrm{~b}$ \\
\hline
\end{tabular}

\subsection{Seed quality attributes of late jute}

Genotypic influence on jute seed quality attributes are presented in table 7. Maximum germination (94.83\%) was found in BJRI Tossa pat-8 $\left(\mathrm{V}_{2}\right)$ followed by CVL-1 $\left(\mathrm{V}_{1}\right)$. Topmost field emergence (88.92) was recorded in $\mathrm{V}_{2}$ genotype that was statistically different from $\mathrm{V}_{1}$. Maximum seed vigour (39.04) was recorded in $\mathrm{V}_{2}$ (CVL-1) genotype and lowest in $\mathrm{V}_{1}$ (BJRI Tossa pat-8) genotype. CVG was maximum (64.76) in $V_{2}$ genotype that was statistically different from $V_{1}$ genotype. Maximum MGT (1.73) was observed in $V_{1}$ genotype that was statistically different from $\mathrm{V}_{2}$ genotype. These variations in seed quality were genotypic.

Effect of herbicide application time on late jute seed quality attributes was found significant for germination (\%), field emergence (\%) seed vigour and MGT (table 8). The plants applied no herbicide showed maximum germination (95.83\%) capability compare to other treatments and lowest was found in found in herbicide applied at $16^{\text {th }}$ days after cutting transplanting. Ratnayake and Shaw (1992) reported that herbicide application seed germination percentage. Maximum field emergence (90.33) was observed in $\mathrm{T}_{0}$ treatment that was statistically similar to $T_{1}$ and $T_{2}$. Lowest field emergence (85.33) was found in $T_{3}$ treatment. Topmost seed vigour (39.29) was found in control plot and lowest (34.68) was recorded in $\mathrm{T}_{3}$ treatment. CVG was not significantly influenced by herbicide application time. Control treatment with no herbicide application was recorded highest (64.29) CVG that was statistically akin to other treatments. Maximum MGT value (1.73) was recorded in herbicide application in at $16^{\text {th }}$ days after cutting transplanting and least MGT value (1.55) was observed in control plot that was statistically different from other treatments.

There was a significant interaction effect of herbicide application time and genotypes on measured quality attribute of late jute seed (table 9). $\mathrm{V}_{2} * \mathrm{~T}_{0}$ treatment combination showed maximum germination capabilities $(97.00 \%)$ that was statistically different from other treatment combinations. $\mathrm{V}_{1} * \mathrm{~T}_{1}$ and $\mathrm{V}_{1} * \mathrm{~T}_{2}$ treatment combinations were showed lowest germination percentage (93.67). Highest field emergence was recorded in $\mathrm{V}_{2} * \mathrm{~T}_{0}$ treatment combination that was statistically akin to all treatment combinations except $\mathrm{V}_{1} * \mathrm{~T}_{3}$ treatment combination. Maximum seed vigour (41.05) was recorded in $\mathrm{V}_{2} * \mathrm{~T}_{0}$ treatment combination and least seed vigour (32.14) was observed in $\mathrm{V}_{1} * \mathrm{~T}_{3}$ treatment combination that was statistically different from others treatment combinations. Highest CVG value (68.41) was found in $\mathrm{V}_{2} * \mathrm{~T}_{0}$ treatment combination that was statistically different from other treatments and minimum CVG value (55.48) was found in $\mathrm{V}_{1} * \mathrm{~T}_{2}$ treatment combination. Maximum MGT value (1.86) was recorded in $\mathrm{V}_{1} * \mathrm{~T}_{2}$ treatment combination and lowest (1.48) in $\mathrm{V}_{2} * \mathrm{~T}_{0}$ treatment combination.

Table 7: Effect of Genotypes on Seed Quality Attributes of Late Jute

\begin{tabular}{lllll}
\hline Genotypes & Germination (\%) & Field emergene (\%) & Seed vigour (\%) & CVG \\
\hline $\mathrm{V}_{1}$ & $92.25 \mathrm{~b}$ & $87.25 \mathrm{~b}$ & $36.07 \mathrm{~b}$ & $57.55 \mathrm{a}$ \\
$\mathrm{V}_{2}$ & $94.83 \mathrm{a}$ & $88.92 \mathrm{a}$ & $39.04 \mathrm{a}$ & $64.76 \mathrm{a}$ \\
$\mathrm{LSD}$ & 1.62 & 1.55 & 2.42 & $1.55 \mathrm{~b}$ \\
$\mathrm{CV}(\%)$ & 1.98 & 2.01 & 7.36 & 0.12 \\
\hline
\end{tabular}

$\mathrm{V}_{1}$ : BJRI tossa pat-8; $\mathrm{V}_{2}$ : CVL-1.

Table 8: Effect of Herbicide Application Time on Seed Quality Attributes of Late Jute

\begin{tabular}{|c|c|c|c|c|c|}
\hline Herbicide application time & Germination (\%) & Field emergence $(\%)$ & Seed vigour (\%) & CVG & MGT \\
\hline $\mathrm{T}_{0}$ & $95.83 \mathrm{a}$ & $90.33 \mathrm{a}$ & $39.29 \mathrm{a}$ & $64.29 \mathrm{a}$ & $1.55 \mathrm{~b}$ \\
\hline $\mathrm{T}_{1}$ & $93.83 \mathrm{a}$ & $88.33 \mathrm{a}$ & $37.49 \mathrm{ab}$ & $61.45 \mathrm{a}$ & $1.63 \mathrm{ab}$ \\
\hline $\mathrm{T}_{2}$ & $93.83 \mathrm{a}$ & $88.00 \mathrm{a}$ & $38.83 \mathrm{a}$ & $60.62 \mathrm{a}$ & $1.67 \mathrm{ab}$ \\
\hline LSD & 2.29 & 2.20 & 3.42 & 6.71 & 0.17 \\
\hline $\mathrm{CV}(\%)$ & 1.98 & 2.01 & 7.36 & 8.87 & 8.44 \\
\hline
\end{tabular}

$\mathrm{T}_{0}$ : Control, $\mathrm{T}_{1}$ : herbicide application at $10^{\text {th }}$ days after cutting transplanting, $\mathrm{T}_{2}$ : herbicide application at $13^{\text {th }}$ days after cutting transplanting, $\mathrm{T}_{3}$ : herbicide application at $16^{\text {th }}$ days after cutting transplanting.

Table 9: Interaction Effect of Genotypes and Treatments on Growth Characteristics of Late Jute Plant

\begin{tabular}{|c|c|c|c|c|c|}
\hline Treatments combinations & Germination $(\%)$ & Field emergence $(\%)$ & Seed vigour $(\%)$ & $\mathrm{CVG}$ & MGT \\
\hline $\mathrm{V}_{1} \times \mathrm{T}_{0}$ & $94.67 \mathrm{ab}$ & $89.67 \mathrm{a}$ & $37.48 \mathrm{a}$ & $60.13 \mathrm{abc}$ & $1.62 \mathrm{abc}$ \\
\hline $\mathrm{V}_{1} \times \mathrm{T}_{1}$ & $93.67 \mathrm{~b}$ & $88.67 \mathrm{a}$ & $37.19 \mathrm{a}$ & $58.71 \mathrm{bc}$ & $1.71 \mathrm{abc}$ \\
\hline $\mathrm{V}_{1} \times \mathrm{T}_{2}$ & $93.67 \mathrm{~b}$ & 88.67 a & $37.44 \mathrm{~b}$ & $55.48 \mathrm{c}$ & $1.86 \mathrm{a}$ \\
\hline $\mathrm{V}_{1} \times \mathrm{T}_{3}$ & $87.00 \mathrm{c}$ & $82.00 \mathrm{~b}$ & $32.14 \mathrm{~b}$ & $55.89 \mathrm{c}$ & $1.89 \mathrm{ab}$ \\
\hline $\mathrm{V}_{2} \times \mathrm{T}_{0}$ & $97.00 \mathrm{a}$ & $91.00 \mathrm{a}$ & $41.05 \mathrm{a}$ & $68.41 \mathrm{a}$ & $1.48 \mathrm{c}$ \\
\hline $\mathrm{V}_{2} \times \mathrm{T}_{1}$ & $94.00 \mathrm{~b}$ & $88.00 \mathrm{a}$ & $37.78 \mathrm{a}$ & $64.18 \mathrm{abc}$ & $1.56 \mathrm{bc}$ \\
\hline $\mathrm{V}_{2} \times \mathrm{T}_{2}$ & $94.00 \mathrm{~b}$ & $88.00 \mathrm{a}$ & $40.22 \mathrm{a}$ & $65.75 \mathrm{ab}$ & $1.52 \mathrm{c}$ \\
\hline $\mathrm{V}_{2} \times \mathrm{T}_{3}$ & $94.33 \mathrm{~b}$ & $88.67 \mathrm{a}$ & $37.11 \mathrm{a}$ & $60.71 \mathrm{abc}$ & $1.65 \mathrm{abc}$ \\
\hline CV $(\%)$ & 1.98 & 2.01 & 7.36 & 8.87 & 8.44 \\
\hline
\end{tabular}

\subsection{Economic analysis}


The economic analysis showed that interaction effect of various herbicide application times and genotypes considerably influenced the net income and benefit-cost ratio for late jute seed production (Tables 10). For BJRI tossa pat- 8 herbicide application at $10^{\text {th }}$ day after cutting transplanting showed maximum in net income and benefit-cost ratio as compared with other treatments. For BJRI tossa pat-8 all other treatment showed negative benefit cost ratio. In CVL-1 herbicide application at $13^{\text {th }}$ days after cutting transplanting attained highest net income and benefit cost ratio compare to other treatments.

Table 10: Economic Analysis of Herbicide Application Time and Genotype on Late Jute Seed Production (Chorchorus Species.)

\begin{tabular}{llll}
\hline Treatment combination & Total expense (US\$ ha-1) & Gross income (US\$ ha-1) & Net income (US\$ ha-1) \\
\hline $\mathrm{V}_{1} \times \mathrm{T}_{0}$ & 2420 & 2103 & -317 \\
$\mathrm{~V}_{1} \times \mathrm{T}_{1}$ & 1995 & 2035 & 40 \\
$\mathrm{~V}_{1} \times \mathrm{T}_{2}$ & 1995 & 1877 & -118 \\
$\mathrm{~V}_{1} \times \mathrm{T}_{3}$ & 1995 & 1809 & -186 \\
$\mathrm{~V}_{2} \times \mathrm{T}_{0}$ & 2530 & 3547 & 0.02 \\
$\mathrm{~V}_{2} \times \mathrm{T}_{1}$ & 2157 & 3190 & 1017 \\
$\mathrm{~V}_{2} \times \mathrm{T}_{2}$ & 2157 & 3619 & 1033 \\
$\mathrm{~V}_{2} \times \mathrm{T}_{3}$ & 2157 & 3000 & 1.94 \\
\hline
\end{tabular}

\subsection{Economics of herbicide and genotypes interaction effect}

Maximum benefit cost ratio was found in herbicide applied at $13^{\text {th }}$ days after cutting transplanting of $\mathrm{V}_{2}$ genotype though maximum seed was in $\mathrm{V}_{2} * \mathrm{~T}_{0}$ treatment combination. That was due to reduction of weeding cost. For $\mathrm{V}_{1}$ (Corchorus olitorius L.) genotype positive BCR only recorded in $\mathrm{V}_{1} * \mathrm{~T}_{1}$ treatment combination.

\section{Conclusions}

Herbicide application have very little negative effect on growth, yield and quality of jute seed production but it ensure better benefit cost ratio over control on both genotypes

\section{Conflict of Interest}

The authors declare that they have no conflict of interest.

\section{Acknowledgements}

The author expresses thanks and gratitude to all the persons of Jute Agricultural Experimental Station of Bangladesh Jute Research Institute for their patience and sincere help in field and laboratory analysis. The author also expresses her heartiest gratitude to all co-authors for their important technical as well as practical assistance in data collection, analysis and reporting regarding this research work.

\section{References}

[1] Alam, A.T.M.M. 2003. "Present status and future strategies of weed management in jute field". Jute and Jute Fabrics, Bangladesh. News letter of Bangladesh Jute Res. Inst. January-March. pp. 4-6.

[2] Alam, M. A., M.A.F. Mollah, Z.A. Rafiq, M.S.A. Sarker, M.N.H. Rony and M.Z. Tareq. 2019. Effect of plant age for cuttings on the growth and seed yield in late season jute under different planting spacings. J. Expt. Biosci. 10(2):1-8. https://www.researchgate.net/publication/324983236

[3] Ali, S. M., M. M. Haque, A. B. Siddique, A. F. Mollah and M. N. Islam. 2003. Phenology growth and seed yield of tossa jute (Corchorus olitorius L.) in late sown technology. Bangladesh J. of Agri. 27 \& 28: 91-97.

[4] BBS. 2018. Statistical Yearbook of Bangladesh. Bangladesh Bureau of Statistics. Ministry of Planning and Statistics Division, Govt. of People's Republic of Bangladesh, Dhaka. Pp. 170. Website: http://www.bbs.gov.bd

[5] Bennett, A.C. and D.R. Shaw. 2000. Effect of pre-harvest desiccants on weed seed production and viability. Weed Technol. 14, 530-538. https://doi.org/10.1614/0890-037X(2000)014[0530:EOPDOW]2.0.CO;2.

[6] Das, M., P. Poddar, S. Haque, S. Pati, R. Poddar and C.K. Kundu. 2014. Yield and economics of white jute as influenced by different dates of sowing, spacing and topping schedule in Terai region of West Bengal. In. J. of Farm Sci. 4(4): 51-58. doi: 10.5958/2250-0499.2020

[7] Datta, M.K., P. Hslder, U. Biswas and C.K. Kundu. 2017. Effect of Different Weed Management Practices on Growth and Yield of Tossa Jute (Corchorus olitorius) in the New Alluvial Zone of West Bengal, India. Int. J. Curr. Microbiol. App. Sci. 6(11): 1118-1123. https://doi.org/10.20546/ijcmas.2017.611.132.

[8] Ghorai, A.K., A.K. Chakraborty, N.C. Pandit, R.K. Mondal and C.R. Biswas.2004. Grass weed control in jute by Targa super (quizalofop-ethyl 5\% EC). Pestology 28: 31-34.

[9] Ghorai, A.K., H. Chowdhury, M. Kumar and S. Kumar. 2013. Technology for weed management in Jute. Indian Farming 63(6): 12-14.

[10] Ghosh, R.K., T. Sreewongchai, S. Nakasathien and C. Phumichai. 2013. Phenotypic variation and the relationships among jute (Corchorus species) genotypes using morpho-agronomic traits and multivariate analysis. AJCS 7(6):830-842. https://www.researchgate.net/publication/268391162

[11] Gianessi, L. P. 2013. The increasing importance of herbicides in worldwide crop production, Pest Manage. Sci. 69 (10):1099-1105. https://doi.org/10.1002/ps.3598.

[12] Hossain, M.B., S. Haque and H. Khan, 2002. DNA Fingerprinting of jute germplasm by RAPD. J. Biochem. Mol. Biol. 35:414-419. https://doi.org/10.5483/BMBRep.2002.35.4.414.

[13] Hossen M., M.S. Ali, M. Begum, A. Khatton and A. Halim. 2008. Study on high yield of quality jute seed production for diversified uses. J Innov. Dev. Strategy. 2:71-73.

[14] Islam, M. 2014. Research Advances of Jute Field Weeds in Bangladesh: A Review. ARPN J. of Sci. and Tech. 4(4): 242.268.

[15] Islam, M. 2009. Jute Seed Technology. 397, Middle Monipur, Mirpur, Dhaka. p. 01.

[16] Mamun. M., C. K. Saha, M. G. Mostofa, A. Miah and M. Z. Hossain. 2017. Identification of suitable varieties for seed production of jute in nontraditional areas of Bangladesh. Bangladesh J. Pl. Breed. Genet. 30(1): 33-37. https://www.researchgate.net/publication/328252829. https://doi.org/10.3329/bjpbg.v30i1.36531. 
[17] Mir, R.R., S. Rustgi, S. Sharma, R. Singh, A. Goyal, J. Kumar, A. Gaur, A.K. Tyagi, H. Khan, M.K. Sinha, H.S. Balyan, and P.K. Gupta. 2008. A preliminary genetic analysis of fiber traits and the use of new genomic SSRs for genetic diversity in jute. Euphytica. 161:413-42. https://doi.org/10.1007/s10681-007-9597-x.

[18] Parvez, M. S., M.A. Salam, H.K. Noguchi and M. Begum. 2013. Effect of cultivar and weeding regime on the performance of transplant aman rice, Intl. J. Agri Crop Sci. Vol., 6 (11):654-666.

[19] Ratnayake, S. and D.R. Shaw. 1992. Effects of harvest aid herbicides on sicklepod (Cassia obtusifolia) seed yield and quality. Weed Technol. 6:985-989. https://doi.org/10.1017/S0890037X00036587.

[20] Saha, C.K. 2011. Jute Seed Management in Bangladesh. Proceedings, International Seminar on Strengthening of Collaboration for Jute, Kenaf and Allied Fibres Research and Development, 2011. International Jute Study Group (IJSG), Dhaka, Bangladesh.

[21] Sarkar S. 2006. Weed management in jute (Corchorus olitorius L.) by post emergence herbicides. J. of Trop. Agri. 44 (1-2): $71-73$.

[22] Saunders, M. 2001. Recovery plan for the endangered native jute species, Corchorus cunninghamii F. Muell in Queensland (2001-2006). Natural Heritage Trust, Australia, pp. 1-29.

[23] Shah, M.A., A. Manaf, M. Hussain, S. Farooq and M.Z.U. Hye. 2013. Sulphur fertilization improves the sesame productivity and economic returns under rain-fed conditions. Int. J. Agric. Biol 15:1301-1306.

[24] Simmons, B., 2006. Soil properties and herbicide behavior, Proceedings: Indiana CCA Conference, Indianapolis.

[25] Sinha, N.K., D. Singh and D.K. Roy. 2009. Weed management strategies in jute grown for seed production in calcareous soils of north Bihar. Indian J. of weed Sci. 41(1\&2), 19-22.

[26] Wilson, R.G. and J.A. Smith. 2002. Influence of harvest aid herbicides on dry bean (Phaseolus vlugaris) desiccation, seed yield, and quality. Weed Technol. 16, 109-166. https://doi.org/10.1614/0890-037X(2002)016[0109:IOHAHO]2.0.CO;2.

[27] Zhang, T., E.N. Johnson and V.J. Willenborg. 2016. Evaluation of harvest aid herbicides as desiccants in lentil production. Weed. Technol. 30, 629-638. https://doi.org/10.1614/WT-D-16-00007.1. 